\title{
FIRST FOSSIL FIND OF THE BLANUS STRAUCHI COMPLEX (AMPHISBAENIA, BLANIDAE) FROM THE MIOCENE OF ANATOLIA
}

\author{
GEORGIOS L. GEORGALIS, ${ }^{*}, 1,2$ KAZIM HALAÇLAR,,${ }^{3,4}$ SERDAR MAYDA, ${ }^{3}$ TANJU KAYA, ${ }^{3}$ and DINÇER AYAZ ${ }^{3}$; \\ ${ }^{1}$ Department of Geosciences, University of Fribourg/Freiburg, Chemin du Musée 6, 1700 Fribourg, Switzerland, \\ georgios.georgalis@unifr.ch; ${ }^{2}$ Dipartimento di Scienze della Terra, Università di Torino, Via Valperga Caluso 35, 10125 Torino, \\ Italy; ${ }^{3}$ Department of Biology, Ege University, Bornova, 35100 Izmir, Turkey; ${ }^{4}$ Institute of Vertebrate Paleontology and \\ Paleoanthropology (IVPP), University of Chinese Academy of Sciences, Beijing
}

Citation for this article: Georgalis, G. L., K. Halaçlar, S. Mayda, T. Kaya, and D. Ayaz. 2018. First fossil find of the Blanus strauchi complex (Amphisbaenia, Blanidae) from the Miocene of Anatolia. Journal of Vertebrate Paleontology. DOI: 10.1080/02724634.2018.1437044.

Worm lizards (Amphisbaenia) constitute a bizarre and specialized clade of mostly limbless, burrowing reptiles. Their exact affinities within other squamates have not yet been fully resolved, with different phylogenetic topologies arising on the basis of external morphology and/or skeletal anatomy (Estes et al., 1988; Kearney, 2003; Conrad, 2008; Gauthier et al., 2012), molecular data (Townsend et al., 2004; Vidal and Hedges, 2009; Pyron et al., 2013; Reeder et al., 2015), and fossil finds (Müller et al., 2011; Čerñanský et al., 2015a; Tałanda, 2016), with a sister-group relationship with lacertids seeming probable (Townsend et al., 2004; Vidal and Hedges, 2009; Müller et al., 2011; Čerňanský et al., 2015a). Blanus is an amphisbaenian genus, long placed within Amphisbaenidae, until it was recently reallocated to its own family, Blanidae, by Kearney (2003), who further suggested a basal position within Amphisbaenia as a whole. The genus currently comprises eight extant species, all limbless forms, with a rather disjunct circum-Mediterranean distribution (Sindaco and Jeremčenko, 2008). Two species complexes are currently recognized: a western one, the Blanus cinereus complex, distributed in the Iberian Peninsula and northwestern Africa (Albert et al., 2007; Albert and Fernández, 2009), and an eastern one, the Blanus strauchi complex, distributed in southern Anatolia, some islands of the Aegean Sea, and parts of Iraq, Syria, Lebanon, and Israel (Sindaco et al., 2014). This disjunct distribution of extant Blanus is apparently the relic of a much wider distribution, as it is revealed from fossils attributed to blanids originating from different European localities dating as far back as the early Eocene (Augé, 2005, 2012; Folie et al., 2013) and continuing until the Quaternary (Delfino, 1997, 2003). The earliest occurrence of the genus Blanus, is represented by the type material of Blanus thomaskelleri Cerňanský, Rage, and Klembara, 2015b, from the early Miocene (MN 2, Aquitanian) of Amöneburg, Germany, although additional finds from Oschiri, Sardinia, Italy, referred by Venczel and Sanchiz (2006) to Blanus gracilis (Roček, 1984), could be even older, as age estimations of the latter locality range between MN 1 and MN 5. Whereas fossils of Blanus are relatively common in central and western Europe (Bolet et al., 2014), they appear to be absent from the eastern Mediterranean region. Indeed, fossil remains of the Iberian Blanus cinereus complex, are well known and readily identifiable (Blain et al., 2007), but this is not the case for the $B$.

*Corresponding author.

Color versions of one or more of the figures in the article can be found online at www.tandfonline.com/ujvp. strauchi complex, no fossils of which have been known up to now (Villa et al., 2017). Furthermore, blanids can only be identified in the fossil record on the basis of cranial remains, because amphisbaenian vertebrae, which are frequently found in the European Neogene, cannot be identified with certainty to the family level (Estes, 1983; but see Augé [2012] for vertebrae of certain Paleogene amphisbaenians). The only two published records to date of fossil amphisbaenians from the eastern Mediterranean are based exclusively on vertebrae and originate from the Miocene of Plakias, Greece (Georgalis et al., 2016b), and the Pliocene of Calta, Turkey (Rage and Sen, 1976). Although on the basis of a biogeographic rationale these two records probably belong to blanids, no such assignment can be made with certainty, especially given the fact that the latter material was never figured or adequately described. Here we describe a cranial element from the middle Miocene locality of Gebeceler, Turkey, that represents the first fossil find of a member of the Blanus strauchi complex and the sole confirmed fossil occurrence of the genus Blanus in the eastern Mediterranean region.

Institutional Abbreviations-EUNMH PV, Natural History Museum of Ege University, Izmir, Turkey; MNCN, Museo Nacional de Ciencias Naturales, Madrid, Spain; NHMC, Natural History Museum of Crete, Herakleion, Greece; NHMW, Naturhistorisches Museum Wien, Vienna, Austria.

\section{MATERIALS AND METHODS}

The amphisbaenian dentary described herein originates from the middle Miocene locality of Gebeceler, Turkey. The material is permanently housed in the collections of the EUNMH PV and is accessioned under the number 17151. Comparative skeletal material of extant blanid specimens includes specimens housed in the collections of MNCN, NHMC, and NHMW, as well as published figures in Schleich (1985), Folie et al. (2013), and Bolet et al. (2014).

\section{LOCALITY}

The Gebeceler Formation characterizes a middle Miocene continental deposit situated in the Afyon region, western Turkey (Fig. 1). The formation is composed of alluvial deposits at its base that grade upwards into volcanosedimentary lacustrine sediments. It comprises syn-sedimentary volcanoclastic units of alkaline volcanism and ends in a silicified limestone facies with a $40 \mathrm{~m}$ thickness. The Gebeceler fossil locality is exposed at the base of the lacustrine unit, characterized by fine clastics that represent lacustrine shore-zone sedimentation. The greenish, 


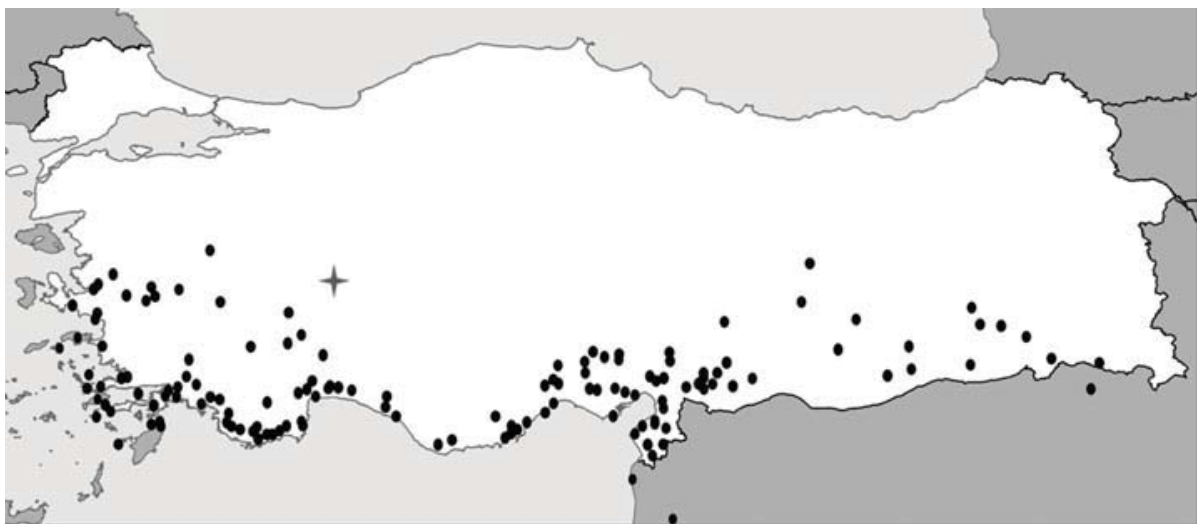

FIGURE 1. Map of Turkey and nearby regions, indicating the range of the extant Blanus strauchi complex (circles) and the fossil locality of Gebeceler (star). The distribution of extant taxa follows Tok et al. (2012) and Sindaco et al. (2014). massive sandstone-claystone level has yielded a local mammalian fauna consisting of the rhinocerotid Hispanotherium grimmi, the equid Anchitherium sp., and the ruminants Triceromeryx sp. and Micromeryx flourensianus (Saraç, 2003). Recently, the fauna was revised by Mayda et al. (2013), with the rhinocerotid and ruminant remains being attributed to $\mathrm{Cae}$ mentodon cf. caucasicum, a new species of Giraffokeryx, and Hispanomeryx sp., respectively, and a new spalacid record, Sinapospalax cf. berdikensis, was added. The latter micromammal from Gebeceler provides further support for assigning the locality to late MN 6 or most probably to the base of MN 7/8 in the European mammal zonation. This is also in agreement with the age of the Susuz-Yaylacilar locality (MN 7/8) (Sickenberg et al., 1975), which is located in the upper levels of the Gebeceler Formation.

\section{SYSTEMATIC PALEONTOLOGY \\ REPTILIA Laurenti, 1768 \\ SQUAMATA Oppel, 1811 \\ AMPHISBAENIA Gray, 1844 \\ BLANIDAE Kearney, 2003 \\ $B L A N U S$ Wagler, 1830 \\ BLANUS STRAUCHI (Bedriaga, 1884) \\ $B L A N U S$ cf. STRAUCHI \\ (Fig. 2)}

Material-EUNMH PV-17151, one right dentary (Fig. 2).

Description-EUNMH PV-17151 represents a right dentary. The specimen is relatively small, with a maximum length of $3.6 \mathrm{~mm}$. Its anterior-most portion, including the edge of the symphysis, is not preserved. The dentary bears six complete teeth and one further incomplete tooth, but it seems that there is also one other tooth position in the anterior part of the specimen. Thus, the total number of teeth should equal eight. The dentition is subpleurodont and highly heterodont, with all teeth differing in terms of shape, height, and base diameter. The second preserved tooth (occupying the third tooth position in life), which is not complete, seems to have been large, judging from the diameter of its base. All teeth are monocuspid, conical, robust, slightly recurved, although not all of them to the same degree, and bear no striations. The apices of the teeth are oriented dorsally. The fifth preserved tooth (the sixth in life) is the largest and most robust. The posterior-most tooth is the smallest one. Resorption pits are present and are circular in shape. The dentary increases in height posteriorly. The coronoid process is not preserved and therefore its extent cannot be assessed, but on the basis of the curvature of the coronoid facet, which is also incomplete, it does not seem to have been high. In lingual view, Meckel's groove is fully open, relatively narrow in the anterior part of the dentary but wide in the posterior part (after the fifth preserved tooth), and forms a narrow groove that runs parallel to the ventral border of the bone. The interdental distance is relatively large (as is common for Blanus strauchi and the extinct Blanus gracilis), with the exception of the first two preserved teeth, which are rather closely spaced. Above Meckel's groove, there is a rather prominent and thickened subdental shelf (sensu Rage and Augé, 2010) that only narrows at the level of the posterior-most tooth and has a ventral margin that is relatively curved, especially at the level of the fifth preserved tooth. There is an acute angle formed between the ventral margins of the dentary and the posterior portion of the symphysis. The ventral margin of the dentary is relatively concave. The intramandibular septum is preserved. In labial view, there are two rather enlarged labial foramina, one at the level of the interdental gap between the second and third preserved teeth, the other at the level of the interdental gap between the fifth and sixth ones. An additional, poorly preserved labial foramen seems also to be probably present just anterior to the level of the first preserved tooth. In dorsal view, the dentary is slightly convex labially. The sulcus dentalis is not much expanded medially.

\section{DISCUSSION}

The Gebeceler dentary can be safely attributed to Blanus on the basis of the shape of the teeth (conical, robustly built, and slightly recurved, with their apices oriented dorsally) and the low number of teeth (probably eight), of which the third is enlarged: all features characteristic of the genus (Gans and Montero, 2008; Bolet et al., 2014; Čerňanský et al., 2015b).

Eight fossil taxa have been attributed to Blanidae, all from the European continent. The early Eocene taxon Blanosaurus primeocaenus Folie, Smith, and Smith, 2013, from Belgium and France, and the middle Eocene Cuvieribaena carlgansi Čerňanský, Augé, and Rage, 2015a, and Louisamphisbaena ferox Augé, 2012, both from France, have been suggested to represent the earliest named blanids (Augé, 2012; Folie et al., 2013; Čerñanský et al., 2015a), extending the fossil record of the clade well back into the Paleogene. Furthermore, the Paleogene record of the group appears not to be confined to these two taxa, as judged by several other finds across the Eocene of France (Augé, 2012) and Spain (Bolet and Evans, 2013) and the Oligocene of France (Rage and Augé, 2015) and Germany (Schleich, 1988; Čerñanský et al., 2016). Whether these Paleogene forms indeed belong to blanids, however, remains to be tested on the basis of more complete material and an extensive phylogenetic analysis including multiple fossil amphisbaenians. During the Neogene, blanids appear to have been diverse, especially across 
A

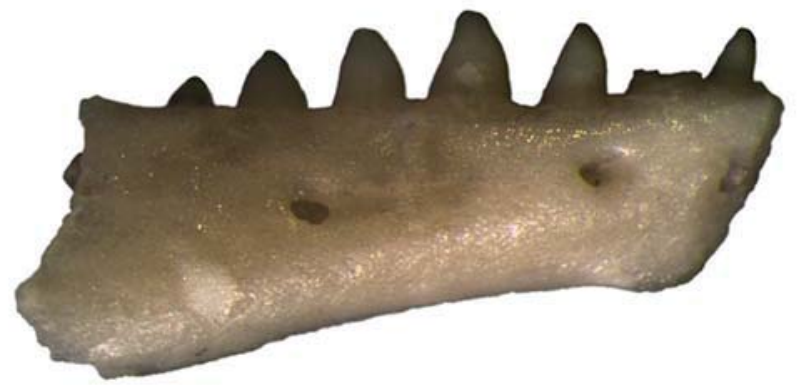

B

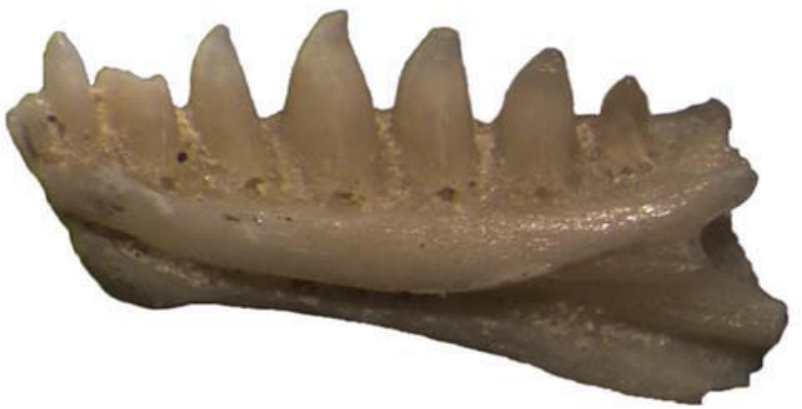

C

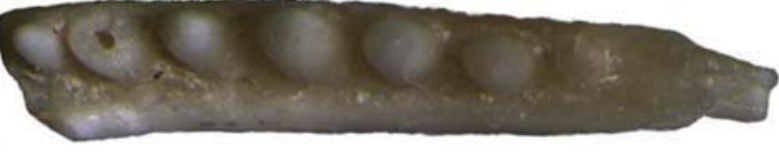

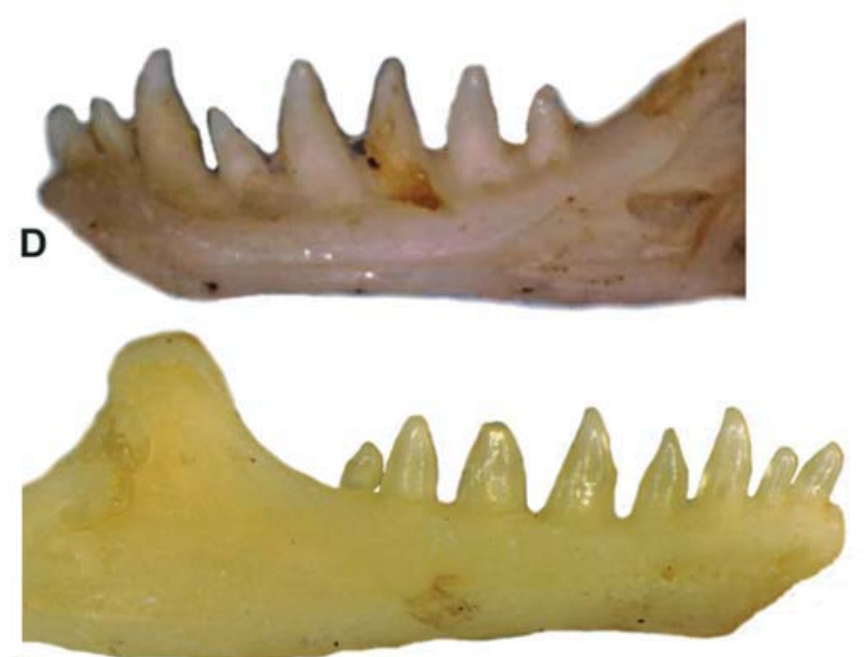

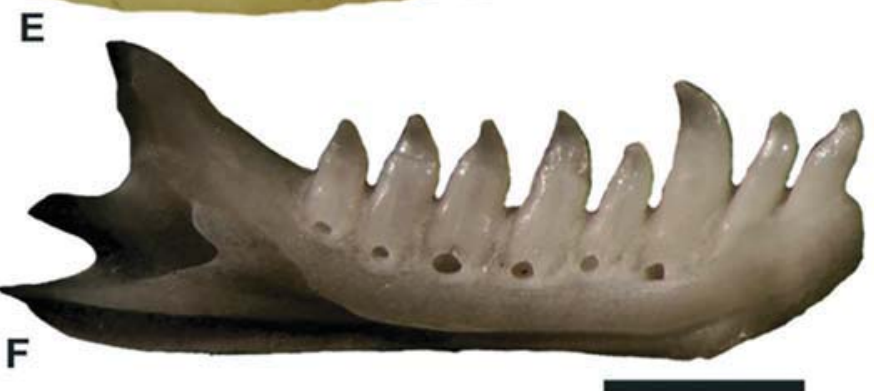

FIGURE 2. Dentaries of extinct and extant Blanus spp. A-C, right dentary (EUNMH PV-17151) of Blanus cf. strauchi from the middle Miocene of Gebeceler, Turkey, in labial (A), lingual (B), and dorsal (C) views; D, right dentary (NHMC 80.3.111.24) of an extant, freshly dissected, B. strauchi from Nisyros Island, Greece, in lingual view; E, right dentary (NHMW 18352:7) of an extant B. strauchi from Dodurga, Turkey, in labial view; F, left dentary (MNCN 16533) of an extant B. cinereus from San Agustín de Guadalix, Madrid, Spain, in lingual view. Scale bar equals $1 \mathrm{~mm}$.

the Miocene. Named forms include Blanus antiquus Schleich, 1985, from the middle Miocene of Austria, France, and Germany (Schleich, 1985; Böhme, 1999; Miklas-Tempfer, 2003), Blanus gracilis (Roček, 1984) from the early Miocene of the Czech Republic and Italy (Roček, 1984; Venczel and Sanchiz, 2006), Blanus mendezi Bolet, Delfino, Fortuny, Almécija, Robles, and Alba, 2014, from the middle Miocene of Spain (Bolet et al., 2014), Blanus thomaskelleri Čerňanský, Rage, and Klembara, 2015b, from the early Miocene of Germany and the Czech Republic (Čerňanský et al., 2015b), and Palaeoblanus tobieni Schleich, 1988, from the early Miocene of Germany (Schleich, 1988). The new Gebeceler blanid described herein appears to be quite distinct from the Paleogene taxa in terms of general shape, robustness of teeth, and curvature of the ventral margin of the dentary; besides, it lacks the amblyodont dentition and the increasing size of teeth towards the symphysis, features that are characteristic of $C$. carlgansi. Among the Miocene taxa, resemblance is more notable. The new Anatolian form can be readily differentiated from Palaeoblanus tobieni, because in the latter taxon the first tooth is the most enlarged and bears dorsoventral slopes on its tooth crowns (Schleich, 1988; Čerñanský et al., 2015b). In comparison with Blanus antiquus and Blanus mendezi, the new specimen can be distinguished mostly by the shape of teeth, the thickness of the subdental shelf, the size of interdental gaps, and the different degree of heterodonty. In terms of size, the Gebeceler form most closely approaches Blanus gracilis, which is characterized by a rather small dentary size (Roček, 1984). This fact is interesting, taking into consideration that the latter species was considered as the probable sister group of
Blanus strauchi by Bolet et al. (2014). The geographically most proximal fossil blanid to our new find is the material described as Blanus cf. gracilis from the middle Miocene of Romania (Venczel and Știucă, 2008). This is also distinct from EUNMH PV17151 in terms of thickness of the subdental shelf, curvature of the ventral margin of the dentary, and shape of the teeth, although these characters may be related to intraspecific variability. Referral of blanid material from the early Pleistocene of Apulia, southern Italy, to Blanus cf. strauchi by Holman (1998) was soon after shown to be erroneous by Delfino and Bailon (2000), who figured and described that material in detail. Concerning the extant taxa, EUNMPH PV-17151 can only be provisionally differentiated from Blanus strauchi by the greater robustness of its teeth, thicker subdental shelf, and a more recurved ventral margin of the dentary, and from Blanus cinereus by the different shape and curvature of the teeth, a larger interdental gap, and a more open Meckel's groove in the posterior part of the dentary (Fig. 2). Nevertheless, these differences should be taken with caution, because there is great variability observed within extant blanids; moreover, dentaries appear to have less diagnostic characters in comparison with maxillae (Bolet et al., 2014). Indeed, features such as the shape, curvature, robustness, and number of dentary teeth appear to be highly variable in extant Blanus spp., with different tooth counts observed, ranging between seven and nine (Bailon, 1991; Cerňanský and Venczel, 2011; Bolet et al., 2014). Besides, a splenial is not present in the new Anatolian fossil; however, this element has been occasionally observed in certain specimens of Blanus cinereus (e.g., Blain et al., 2007), and as such, this feature 
is subject to individual variation and has no taxonomic utility. Furthermore, the splenial is usually an easily disarticulated bone, and its absence from a specimen may not indicate true absence from that individual in life. The coronoid process, a feature that has often been used to diagnose extinct taxa (e.g., Roček 1984; Cerňanský et al., 2015b), is not preserved in the Anatolian specimen.

The new fossil find described herein originates from a locality that is only situated a few kilometers outside the known geographic range of the extant Blanus strauchi complex in Anatolia (Fig. 1). It is worth noting that a significant amount of cryptic variation has been observed in this complex (as is also the situation in the Blanus cinereus complex), and as such, it has recently been split by Sindaco et al. (2014) into distinct species: the nominal species Blanus strauchi (Bedriaga, 1884) (with two subspecies, Blanus strauchi strauchi and Blanus strauchi bedriagae [Boulenger, 1884]), distributed in western and southwestern Anatolia and certain islands of the eastern Aegean Sea (Samos, Fournoi, Leros, Kos, Symi, Pserimos, Telendos, Nisyros, Rhodes, and Kastellorizon), Blanus aporus Werner, 1898, distributed in south-central and southeastern Anatolia, and Blanus alexandri Sindaco, Kornilios, Sacchi, and Lymberakis, 2014, from southeastern Anatolia and parts of Syria, Iraq, and maybe Israel (Sindaco et al., 2014). Nevertheless, these taxa were defined solely on the basis of molecular data and/or external morphology, and their skeletal differentiation (if any exists) is not known. Given the great variability observed in both extant and extinct blanids that was discussed above, we are here reluctant to name EUNMH PV-17151 as a new taxon, and considering its overall resemblance with the extant members of the Blanus strauchi complex, and using also a biogeographic rationale, we refer this specimen to Blanus cf. strauchi. Of course, we note here that the assignment of this Miocene specimen to Blanus cf. strauchi does not necessarily indicate that the fossil form has closer affinities with Blanus strauchi sensu stricto than with its cryptic Anatolian congeners B. aporus and B. alexandri. Rather, we use this taxonomic allocation as a convenience for denoting assignment of the fossil material to the Blanus strauchi complex.

The new Blanus from Gebeceler confirms the presence of the B. strauchi complex in Anatolia as far back as at least the middle Miocene (MN 6 or MN 7/8) and, furthermore, represents the sole verified occurrence of the genus in the eastern Mediterranean. Additionally, the new find represents the only Miocene squamate currently described from Turkey, with the only exception of recently reported anguid finds (Čerňanský et al., 2017). Frustratingly, the scarceness of fossil squamate material from Anatolia and the southern Balkans hinders our understanding of the palaeobiogeography of Blanidae. The wide distribution of Blanus spp. in central Europe during the early and middle Miocene is contradicted by the modern disjunct geographic range of the genus; however, the recent find of $B$. mendezi in the middle Miocene of Spain (Bolet et al., 2014) and the new middle Miocene Turkish Blanus described herein both confirm a much wider distribution and reveal that the present range of the genus was already inhabited at least as far back as that time. In any case, a post-Miocene southward restriction of the blanid geographic range, as has been variously suggested (e.g., Delfino, 2003), is also supported here and is reminiscent of the case of certain other European reptile clades, such as agamids, large-sized anguids, scolecophidians, boids, 'Oriental vipers,' geoemydids, giant testudinids, and pan-trionychids (Szyndlar, 1991; Bailon and Blain, 2007; Chesi et al., 2007; Delfino et al., 2008; Georgalis and Kear, 2013; Rage, 2013; Georgalis et al., 2016a, 2017; Georgalis and Joyce, 2017). More fossil squamates from Anatolia are definitely needed in order to clarify paleobiogeographic assumptions, as this region has repeatedly acted as a 'refugium' for multiple reptile groups, a fact also suggested by its current herpetofaunal synthesys and molecular data (Kornilios et al., 2011).

\section{ACKNOWLEDGMENTS}

We would like to thank P. Lymberakis (NHMC), M. Calvo Revuelta (MNCN), and G. Gassner and C. Hörweg (NHMW) for providing access to specimens under their care and photographs of extant specimens of Blanus spp. M. Delfino (University of Torino) provided insightful comments that enhanced the quality of the manuscript. A. Villa (University of Torino) helped with the literature. G.L.G. acknowledges travel support from SYNTHESYS (grant SYNTHESYS ES-TAF-5910) and the University of Torino. K.H., S.M., and T.K. were supported by TUBITAK-RFBR 111Y192 and Ege University Research Projects TTM/001/2010, TTM/002/2011, TTM/001/2013, TTM/002/ 2014, and 2015/Fen/17 during their field trips. We also thank Editor J. Head and the reviewers A. Bolet and J. Müller for their comments and help during the review process.

\section{LITERATURE CITED}

Albert, E. M., and A. Fernández. 2009. Evidence of cryptic speciation in a fossorial reptile: description of a new species of Blanus (Squamata: Amphisbaenia: Blanidae) from the Iberian Peninsula. Zootaxa 2234:56-68.

Albert, E. M., R. Zardoya, and M. García-París. 2007. Phylogeographical and speciation patterns in subterranean worm lizards of the genus Blanus (Amphisbaenia: Blanidae). Molecular Ecology 16:15191531.

Augé, M. 2005. Evolution des lézards du Paléogène en Europe. Publications Scientifiques du Muséum, Mémoires du Muséum national d'Histoire naturelle, Paris 192:1-369.

Augé, M. 2012. Amphisbaenians from the European Eocene: a biogeographical review. Palaeobiodiversity and Palaeoenvironments 92:425-443.

Bailon, S. 1991. Amphibiens et reptiles du Pliocène et du Quaternaire de France et d'Espagne: mise en place et évolution des faunes. Ph.D. dissertation, Université de Paris VII, Paris, France, 499 pp.

Bailon, S., and H.-A. Blain. 2007. Faunes de reptiles et changements climatiques en Europe occidentale autour de la limite PlioPléistocène. Quaternaire 18:55-63.

Bedriaga, J. 1884. Nachträgliche Bemerkung über Amphisbaena strauchi v. Bedr. Zoologischer Anzeiger 7:346.

Blain, H.-A., S. Bailon, and J. Agusti. 2007. Anurans and squamate reptiles from the latest early Pleistocene of Almenara-Casablanca-3 (Castellón, East of Spain). Systematic, climatic and environmental considerations. Geodiversitas 29:269-295.

Böhme, M. 1999. Doppelschleichen (Sauria, Amphisbaenidae) aus dem Untermiozän von Stubersheim 3 (Süddeutschland). Mitteilungen der Bayerischen Staatssammlung für Paläontologie und Historische Geologie 39:85-90.

Bolet, A., and S. E. Evans. 2013. Lizards and amphisbaenians (Reptilia, Squamata) from the late Eocene of Sossís (Catalonia, Spain). Palaeontologia Electronica 16:1-23.

Bolet, A., M. Delfino, J. Fortuny, S. Almécija, J. M. Robles, and D. M. Alba. 2014. An amphisbaenian skull from the European Miocene and the evolution of Mediterranean worm lizards. PLoS ONE 9: e98082.

Boulenger, G. A. 1884. Descriptions of new species of reptiles and batrachians in the British Museum. Annals and Magazine of Natural History, 5th Series 13:396-398.

Čerňanský, A., and M. Venczel. 2011. An amphisbaenid reptile (Squamata, Amphisbaenidae) from the Lower Miocene of Northwest Bohemia (MN 3, Czech Republic). Neues Jahrbuch für Geologie und Paläontologie, Abhandlungen 260:73-77.

Čerňanský, A., M. Augé, and J.-C. Rage. 2015a. A complete mandible of a new amphisbaenian reptile (Squamata, Amphisbaenia) from the late Middle Eocene (Bartonian, MP 16) of France. Journal of Vertebrate Paleontology. doi: 10.1080/02724634.2014.902379.

Čerňanský, A. J. Klembara, and J. Müller. 2016. The new rare record of the late Oligocene lizards and amphisbaenians from Germany and its impact on our knowledge of the European terminal Palaeogene. Palaeobiodiversity and Palaeoenvironments 96:559-587.

Čerňanský, A., J.-C. Rage, and J. Klembara. 2015b. The Early Miocene squamates of Amöneburg (Germany): the first stages of modern 
squamates in Europe. Journal of Systematic Palaeontology 13:97128.

Čerňanský, A., D. Vasilyan, G. L. Georgalis, P. Joniak, S. Mayda, and J. Klembara. 2017. The first records of fossil anguines (Squamata; Anguidae) from the Oligocene and Miocene localities of Turkey. Swiss Journal of Geosciences 110:741-751.

Chesi, F., M. Delfino, L. Abbazzi, S. Carboni, L. Lecca, and L. Rook. 2007. New fossil vertebrate remains from San Giovanni di Sinis (Late Pleistocene, Sardinia): the last Mauremys (Reptilia, Testudines) in the Central Mediterranean. Rivista Italiana di Paleontologia e Stratigrafia 113:287-297.

Conrad, J. L. 2008. Phylogeny and systematics of Squamata (Reptilia) based on morphology. Bulletin of the American Museum of Natural History 310:1-182.

Delfino, M. 1997. Blanus from the early Pleistocene of southern Italy: another small tessera from a big mosaic; pp. 89-97 in I. W. Böhme, W. Bischoff, and T. Ziegler (eds.), Herpetologica Bonnensis, Proceedings of the 8th Ordinary General Meeting of the Societas Euroapaea Herpetologica, Bonn, Germany, 23-27 August 1995.

Delfino, M., 2003. A Pleistocene amphisbaenian from Sicily. AmphibiaReptilia 24:407-414

Delfino, M., and S. Bailon. 2000. Early Pleistocene herpetofauna from Cava Dell' Erba and Cava Pirro (Apulia, Southern Italy). Herpetological Journal 10:95-110.

Delfino, M., T. Kotsakis, M. Arca, C. Tuveri, G. Pitruzzella, and L. Rook 2008. Agamid lizards from the Plio-Pleistocene of Sardinia (Italy) and an overview of the European fossil record of the family. Geodiversitas 30:641-656.

Estes, R. 1983. Sauria Terrestria, Amphisbaenia. Encyclopedia of Paleoherpetology, Part 10a. Gustav Fisher Verlag, Stuttgart and New York, $249 \mathrm{pp}$.

Estes, R., K. de Queiroz, and J. Gauthier. 1988. Phylogenetic relationships within Squamata; pp 99-118 in R. Estes and G. Pregill (eds.), Phylogenetic Relationships of the Lizard Families: Essays Commemorating Charles L. Camp. Stanford University Press, Stanford, California.

Folie, A., R. Smith, and T. Smith. 2013. New amphisbaenian lizards from the Early Paleogene of Europe and their implications for the early evolution of modern amphisbaenians. Geologica Belgica 16:227-235.

Gans, C., and R. Montero. 2008. An atlas of amphisbaenian skull anatomy; pp 621-738 in C. Gans, A. S. Gaunt, and K. Adler (eds.), Biology of the Reptilia. Volume 21. The Skull and Appendicular Locomotor Apparatus of Lepidosauria. Society for the Study of Amphibians and Reptiles, Ithaca, New York.

Gauthier, J. A., M. Kearney, J. A. Maisano, O. Rieppel, and A. D. B Behike. 2012. Assembling the squamate tree of life: perspectives from the phenotype and the fossil record. Bulletin of the Peabody Museum of Natural History 53:3-308.

Georgalis, G. L., and W. G. Joyce. 2017. A review of the fossil record of Old World turtles of the clade Pan-Trionychidae. Bulletin of the Peabody Museum of Natural History 58:115-208.

Georgalis, G. L., and B. P. Kear. 2013. The fossil turtles of Greece: an overview of taxonomy and distribution. Geobios 46:299-311.

Georgalis, G. L., A. Villa, and M. Delfino. 2017. Fossil lizards and snakes from Ano Metochi-a diverse squamate fauna from the latest Miocene of northern Greece. Historical Biology 29:730-742.

Georgalis, G. L., Z. Szyndlar, B. P. Kear, and M. Delfino. 2016a. New material of Laophis crotaloides, an enigmatic giant snake from Greece, with an overview of the largest fossil European vipers. Swiss Journal of Geosciences 109:103-116.

Georgalis, G. L., A. Villa, E. Vlachos, and M. Delfino. 2016b. Fossil amphibians and reptiles from Plakias, Crete: a glimpse into the earliest late Miocene herpetofaunas of southeastern Europe. Geobios 49:433-444.

Gray, J. E. 1844. Catalogue of the Tortoises, Crocodiles, and Amphisbaenians in the Collection of the British Museum. British Museum of Natural History, London, $80 \mathrm{pp}$.

Holman, A. J. 1998. Pleistocene Amphibians and Reptiles in Britain and Europe. Oxford University Press, New York, 254 pp.

Kearney, M. 2003. Systematics of the Amphisbaenia (Lepidosauria: Squamata) based on morphological evidence from recent and fossi forms. Herpetological Monographs 17:1-74.

Kornilios, P., Ç. Ilgaz, Y. Kumlutaş, S. Giokas, S. Fraguedakis-Tsolis, and B. Chondropoulos. 2011. The role of Anatolian refugia in herpetofaunal diversity: an mtDNA analysis of Typhlops vermicularis
Merrem, 1820 (Squamata, Typhlopidae). Amphibia-Reptilia 32:351-363.

Laurenti, J. N. 1768. Specimen medicum, exhibens synopsin reptilium emendatam cum experimentis circa venena et antidota reptilium austracorum, quod authoritate et consensu. Joan Thomae, Vienna, $217 \mathrm{pp}$.

Mayda, S., F. Göktaş, A. S. Tesakov, T. Kaya, V. Titov, and K. Halaçlar. 2013. A new middle Miocene mammalian fauna from Afyon-Gebeceler (Western Turkey); pp. 470-471 in 66th Turkish Geology Symposium Ankara, Turkey, 1-5 May 2013. Abstracts Book.

Miklas-Tempfer, P. M. 2003. The Miocene Herpetofaunas of Grund (Caudata; Chelonii, Sauria, Serpentes) and Mühlbach am Manhartsberg (Chelonii, Sauria, Amphisbaenia, Serpentes), Lower Austria. Annalen des Naturhistorischen Museums in Wien 104:195-235.

Müller, J., C. A. Hipsley, J. J. Head, N. Kardjilov, A. Hilger, M. Wuttke, and R. Reisz. 2011. Eocene lizard from Germany reveals amphisbaenian origins. Nature 473:364-367.

Oppel, M. 1811. Die Ordnungen, Familien, und Gattungen der Reptilien als Prodrom einer Naturgeschichte derselben. Joseph Lindauer, Munich, 86 pp.

Pyron, R. A., F. T. Burbrink, and J. J. Wiens. 2013. A phylogeny and revised classification of Squamata, including 4161 species of lizards and snakes. BMC Evolutionary Biology 13:93.

Rage, J.-C. 2013. Mesozoic and Cenozoic squamates of Europe. Palaeobiodiversity and Palaeoenvironments 93:517-534.

Rage, J.-C., and M. Augé. 2010. Squamate reptiles from the middle Eocene of Lissieu France). A landmark in the middle Eocene of Europe. Geobios 43:253-268.

Rage, J.-C., and M. Augé. 2015. Valbro: a new site of vertebrates from the early Oligocene (MP 22) of France (Quercy). III-amphibians and squamates. Annales de Paléontologie 101:29-41.

Rage, J.-C., and S. Sen. 1976. Les Amphibiens et les Reptiles du Pliocène supérieur de Çalta (Turquie). Géologie méditerranéenne 3:127-134.

Reeder, T. W., T. M. Townsend, D. G. Mulcahy, B. P. Noonan, P. L. Wood Jr., J. W. Sites Jr., and J. J. Wiens. 2015. Integrated analyses resolve conflicts over squamate reptile phylogeny and reveal unexpected placements for fossil taxa. PLoS ONE 10:e0118199.

Roček, Z. 1984. Lizards (Reptilia, Sauria) from the lower Miocene locality Dolnice (Bohemia, Czechoslovakia). Rozpravy Ceskoslovenské Akademie Ved, Rada Matematickych a prírodních Ved 94:3-69.

Saraç, G. 2003. Türkiye Omurgalı Fosil Yatakları. Scientific Report No. 10609. General Directorate of the Mineral Research and Exploration of Turkey (MTA), Ankara, Turkey, 208 pp.

Schleich, H.-H. 1985. Neue Reptilienfunde aus dem Tertiär Deutschlands 3. Erstnachweis von Doppelschleichen (Blanus antiquus sp. nov.) aus dem Mittelmiozän Süddeutschlands. Münchner Geowissenschaftliche Abhandlungen Reihe A 4:1-16.

Schleich, H.-H. 1988. Neue Reptilienfunde aus dem Tertiär Deutschlands. 8. Palaeoblanus tobieni n. gen., n. sp.-neue Doppelschleichen aus dem Tertiär Deutschlands. Paläontologische Zeitschrift 62:95-105.

Sindaco, R., and V. K. Jeremčenko. 2008. The reptiles of the Western Palearctic. 1. Annotated checklist and distributional atlas of the turtles, crocodiles, amphisbaenians and lizards of Europe, North Africa, Middle East and Central Asia. Monografie della Societas Herpetologica Italica, I. Edizioni Belvedere, Latina, Italy, $580 \mathrm{pp}$.

Sindaco, R., P. Kornilios, R. Sacchi, and P. Lymberakis. 2014. Taxonomic reassessment of Blanus strauchi (Bedriaga, 1884) (Squamata: Amphisbaenia: Blanidae), with the description of a new species from south-east Anatolia (Turkey). Zootaxa 3795:311326.

Szyndlar, Z. 1991. A review of Neogene and Quaternary snakes of Central and Eastern Europe. Part I: Scolecophidia, Boidae, Colubrinae. Estudios Geológicos 47:103-126.

Tałanda, M. 2016. Cretaceous roots of the amphisbaenian lizards. Zoologica Scripta 45:1-8.

Tok, C. V., M. Tosunoğlu, D. Ayaz, K. Çiçek, and H. S. Mutlu. 2012. New records of the Anatolian Worm Lizard, Blanus strauchi (Bedriaga, 1884), from Turkey (Squamata: Amphisbaenia: Blanidae). Herpetozoa 24:107-111.

Townsend, T. M., A. Larson, E. Louis, and J. R. Macey. 2004. Molecular phylogenetics of Squamata: the position of snakes, amphisbaenians, 
and dibamids, and the root of the squamate tree. Systematic Biology 53:735-757.

Venczel, M., and B. Sanchíz. 2006. Lower Miocene Amphibians and Reptiles from Oschiri (Sardinia, Italy). Hantkeniana 5:72-75.

Venczel, M., and E. Ştiucă. 2008. Late middle Miocene amphibians and squamate reptiles from Tauţ, Romania. Geodiversitas 30:731-763.

Vidal, N., and B. S. Hedges. 2009. The molecular evolutionary tree of lizards, snakes, and amphisbaenians. Comptes Rendus Biologies 332:129-139.
Villa, A., E. Tschopp, G. L. Georgalis, and M. Delfino. 2017. Osteology, fossil record and palaeodiversity of the European lizards. Amphibia-Reptilia 38:79-88.

Wagler, J. G. 1830. Natürliches System der Amphibien, mit vorangehender Classification der Saügthiere und Vögel. J. G. Cotta, Munich.

Werner, F. 1898. Über einige neue Reptilien und einen neuen Frosch aus dem cilicischen Taurus. Zoologischer Anzeiger 21:217-223.

Submitted June 15, 2017; revisions received November 11, 2017;

accepted November 11, 2017.

Handling editor: Jason Head. 